\author{
A. V. Sinichenko ${ }^{1}$, S. M. MARChYShYN ${ }^{1}$, L. M. SiRA ${ }^{2}$
}

${ }^{1}$ SHEI "I.Ya. Horbachevsky Ternopil State Medical University of Ministry of Healthcare of Ukraine"

${ }^{2}$ National University of Pharmacy

\title{
MACRO- AND MICROSCOPIC INVESTIGATION OF LEAVES AND FLOWERS CULTIVATED SPECIES GENUS PRIMULA L. - DRUMSTICK PRIMROSE
}

Topicality. Many species of genus Primula L. are valuable medicinal and vitamins plants, but analysis of scientific literature demonstrates a lack of systematic information on morphological and anatomical structure of some species of mentioned genus, especially drumstick primrose, so they still remain objects of investigation as perspective.

The aim of these studies was investigation of morphological and anatomical structure above ground organs of drumstick primrose and establishing macro- and microscopic diagnostic features of plants, that are necessary for identification of new plant raw material.

Materials and methods. The objects of the study were leaves and flowers of drumstick primrose harvested during the plants flowering. Microscopic analysis was performed using commonly accepted methodologies, microscopes MBS 9, MS 10, microphotographs made by the Samsung camera PL50.

Results and discussion. As a result of conducted investigation, it was found: 1 . The morphological diagnostic features: leaves without leafstalk, reaches $20-40 \mathrm{~cm}$ in length, collected in a dense rosette. Leaf plate wide thick, elongated, on the edge finely serrated, light green, pubescence, wrinkled and lumpy. Thick peduncles, covered at the top by yellowish cilia. Small flowers on short pedicel, gathered in dense spherical umbrella diameter of 4-10 cm; corolla violet, blue, purple, red, pink or white. 2. Anatomical features: Leaf - leaf plate dorsoventral, hipostomatic; upper epidermis without stomata; lower epidermis of anomocytic type; many specialized cells with orange secret; on the edge of the plate located the teeth of secreting epidermis; lower epidermis densely covered with hairs of two kinds. Peduncles - cylindrical; anatomical structure transition. Primary bark a multilayer, many secretory cells and milkmen with brown contents; ring of conductive bundles narrow; core parenchyma contains many dark secretory structures. Epidermis covered by capitate glandular hairs. Flower - calyx; stomata and hairs absent; contain frequent dark secretory idioblast, veins with segmented milkmen with a yellowish secret. Corolla with secretory cells.

Conclusions. For the first time, has been conducted investigation of morphological and anatomical structure features of leaves and flowers cultivated species genus Primula L. - drumstick primrose, detected their typical macro- and microscopic diagnostic features, that make it possible to identify the flowers and leaves of this species primrose and that used to develop the project of quality control methods for the new medicinal plant raw material.

Key words: drumstick primrose; leaves; flowers; morphological and anatomical structure

\section{А. В. Сініченко, С. М. Марчишин, Л. М. Сіра \\ Макро- і мікроскопічне дослідження листків і квіток культивованого виду роду Primula L. - примули дрібнозубчастої}

Актуальність. Багато видів роду Primula L. є цінними лікарськими і вітамінними рослинами, проте аналіз даних наукової літератури свідчить про відсутність систематизованих відомостей про морфолого-анатомічну будову деяких видів даного роду, зокрема, примули дрібнозубчастої, тому до цих пір вони залишаються об'єктами дослідження як перспективні.

Метою даної роботи було вивчення морфолого-анатомічної будови надземних органів примули дрібнозубчастої та встановлення макро- і мікроскопічних діагностичних ознак рослини, необхідних для ідентифікації нової рослинної сировини.

Матеріали та методи. Об'єктами дослідження були листки і квітки примули дрібнозубчастої, заготовлені під час цвітіння рослини. Мікроскопічний аналіз проводили з використанням загальноприйнятих методик, мікроскопів МБС 9, МС 10, мікрофотографії зроблені фотокамерою Samsung PL50.

Результати та їх обговорення. В результаті проведеного дослідження встановлено: 1. Морфологічні ознаки: листя безчерешкове 20-40 см у довжину, зібране у прикореневу розетку. Листкова пластинка широкоовальна, видовжена, по краю дрібнозазубрена, світло-зелена, опушена, горбкувато-зморшкувата. Квітконіс товстий, вкритий на самій верхівці жовтуватими війками. Квітки дрібні на коротких квітконіжках, зібрані у щільний кулястий зонтик діаметром 4-10 см; віночок фіолетовий, блакитний, бузковий, пурпуровий, рожевий або білий. 2. Анатомічні ознаки: Листок - листкова пластинка дорзовентральна, гіпостоматична; верхня епідерма без продихів; нижня епідерма аномоцитного типу; багато спеціалізованих клітини з оранжевим секретом; по краю зубці з секретуючою епідермою; нижня епідерма густо вкрита волосками двох видів. Квітконіс - циліндричний; анатомічна будова перехідна. Первинна кора багатошарова, багато секреторних клітин і молочників 3 коричневим вмістом; кільце провідних пучків вузьке; серцевинна паренхіма містить багато темних секреторних структур. Епідерма вкрита залозистими головчастими волосками. Квітка - чашечка; продихи і волоски відсутні; містить часті темні секреторні ідіобласти, жилки з членистими молочниками з жовтуватим секретом. Віночок з секреторними клітинами. 
Висновки. Вперше здійснено дослідження особливостей морфологічної та анатомічної будови листків і квіток культивованого виду роду Primula L. - примули дрібнозубчастої, виявлені їх характерні макро- і мікроскопічні діагностичні ознаки, які дають можливість ідентифікувати квітки і листки даного виду примули, які використані для розробки проекту методик контролю якості на нову лікарську рослинну сировину.

Ключові слова: примула дрібнозубчаста; листки; квітки; морфологічна та анатомічна будова

\section{А. В. Синиченко, С. М. Марчишин, Л. М. Серая}

\section{Макро- и микроскопическое исследование листков и цветков культивируемого вида рода Primula L. - примулы мелкозубчатой}

Актуальность. Многие виды рода Primula L. являются ценными лекарственными и витаминными растениями, однако анализ данных научной литературы свидетельствует об отсутствии систематизированных сведений о морфолого-анатомическом строении некоторых видов данного рода, в частности, примулы мелкозубчатой, поэтому до сих пор они остаются объектами исследования как перспективные.

Целью данной работы было изучение морфолого-анатомического строения надземных органов примулы мелкозубчатой и определение макро- и микроскопических диагностических признаков растения, которые необходимы для идентификации нового растительного сырья.

Материалы и методы. Объектами исследования были листья и цветки примулы мелкозубчатой, заготовленные во время цветения растения. Микроскопический анализ проводили с использованием общепринятых методик, микроскопов МБС 9, MC 10, микрофотографии сделаны фотокамерой Samsung PL50.

Результаты и их обсуждение. В результате проведенного исследования установлено: 1 . Морфологические признаки: листья бесчерешковые 20-40 см в длину, собранные в прикорневую розетку. Листовая пластинка широкоовальная, удлиненная, по краю мелкозазубренная, светло-зеленая, опушенная, холмисто-морщинистая. Цветонос толстый, покрыт на самой верхушке желтоватыми ресничками. Цветки мелкие на коротких цветоносах, собраны в плотный шаровидный зонтик диаметром 4-10 см; венчик фиолетовый, голубой, сиреневый, красный, розовый или белый. 2. Анатомические признаки: Листок - листовая пластинка дорсовентральная, гипостоматическая; верхняя эпидерма без устьиц; нижняя эпидерма аномоцитного типа; много специализированных клеток с оранжевым секретом; по краю зубцы с секретирующей эпидермой; нижняя эпидерма густо покрыта волосками двух видов. Цветонос - цилиндрический; анатомическое строение переходное. Первичная кора многослойная, много секреторных клеток и молочников с коричневым содержимым; кольцо проводящих пучков узкое; сердцевинная паренхима содержит много темных секреторных структур. Эпидерма покрыта железистыми головчатыми волосками. Цветок - чашечка; устьица и волоски отсутствуют; содержит частые темные секреторные идиобласты, жилки с членистыми молочниками с желтоватым секретом. Венчик с секреторными клетками.

Выводы. Впервые проведено исследование особенностей морфологического и анатомического строения листьев и цветков культивируемого вида рода Primula L. - примулы мелкозубчатой, выявлены их характерные макро- и микроскопические диагностические признаки, позволяющие идентифицировать цветки и листья данного вида примулы, которые использованы для разработки проекта методик контроля качества на новое лекарственное растительное сырье.

Ключевые слова: примула мелкозубчатая; листья; цветки; морфологическое и анатомическое строение

\section{INTRODUCTION}

Plants of the family Primulaceae, unfortunately, today is poorly studied. There are only a few works, which presented the botanical descriptions of individual species and information on their practical application $[1,4,6,7,9,10]$.

Primula L. largest in the Primulaceae family and accounts, according to various experts, more than 600 species. Types of primroses very diverse by morphological and anatomical features, by the content of biologically active substances, by the application in scientific and folk medicine [1, 2, 4-6, 9, 10]. Many species of genus Primula L. are valuable raw materials, mainly medicinal and vitamins plants, but still they stay objects of investigation as perspective, and many representatives has not yet investigated $[1,2,6,9]$.

Considerable interest makes drumstick primrose (Primula denticulata Smith) - an ornamental plant that attracts by unusual long spherical inflorescences of violet, blue, purple, red, pink or white colors [8].

Drumstick primrose (large flower) (Primula denticulata Smith) - a perennial herbaceous plant. Leaves without leafstalk, reaches $20-40 \mathrm{~cm}$ in length, collected in a dense rosette. At the beginning of development, they rolled spiral. Leaf plate light green, juicy, soft from pubescence, wrinkled, lumpy. The main and lateral parallel veins thick, juicy. The shape of the plate wide thick, elongated, on the edge finely serrated, the base gradually narrowed, represented by wide white main vein on the edge of wavy wings. Thick peduncles, at the beginning of flowering 10-15 cm long, covered at the top by yellowish cilia, in fruiting phase up to $40-50 \mathrm{~cm}$, tubular The flowers on short pedicel, gathered in dense spherical umbrella diameter of $4-10 \mathrm{~cm}$. Corolla violet, blue, purple, red, pink or white. Bend like a wheel, diameter about $1.5 \mathrm{~cm}$. The tube is narrow, longer than the cup. Most flowering in leafless condition. At the beginning of flowering peduncles - no more than $2-3 \mathrm{~cm}$. By the middle flowering blossoms-balls found at a height of $20-25 \mathrm{~cm}$, and on the ripening time seeds, they are extracted to $30-50 \mathrm{~cm}$. Approximately the same happens with the leaves. They begin to unfold at the beginning of flowering, and at this time their length makes $5-7 \mathrm{~cm}$, to the middle of flowering - already $20 \mathrm{~cm}$, after flowering in favorable conditions $-30-40 \mathrm{~cm}$. The whole plant, especially the 
peduncles are covered with yellowish mealy coating. It flowers from April 30-40 days [8].

Data analysis of scientific literature indicates the absence of systematic information about morphological and anatomic structure of variety, including above ground, organs this plant, so the aim of this work was investigation of morphological and anatomical structure above ground organs of drumstick primrose and establishing macro- and microscopic diagnostic features of plants, that are necessary for identification of new plant raw material.

\section{MATERIALS AND METHODS}

For the investigation were used the leaves and flowers of drumstick primrose harvested during the plants flowering (April-May 2015) at the M. M. Gryshko National botanical garden National Academy of Sciences of Ukraine. Microscopic analysis was performed using dried raw materials, fixed in a mixture of alcohol-glycerol-water $(1: 1: 1)$ and including liquids of temporary micropreparations - chloral hydrate and glycerol solutions. Investigation of transverse and longitudinal sections, dissected epidermis and preparations from the surface were carried out using commonly accepted methodologies, microscopes MBS 9, MS 10 (eyeglass X5, X10, 15, lenses X10, H40), microphotographs made by the Samsung camera PL50 $[3,11]$.

\section{RESULTS AND DISCUSSION}

Macroscopic analysis of drumstick primrose leaves

The leaves of drumstick primrose are widely oval, elongated on the edge finely serrated, at the base gradually narrowed, with a broad white main vein with wavy wings on the edge, lumpy-wrinkled, pubescent, without petioles, 20-40 cm long. Color of leaves light green on top, at the bottom - a little lighter. The smell peculiar. The taste is bitter, mucous.

Macroscopic analysis of drumstick primrose flowers

The flowers are small, five-membered, two-tube with separate petals, calyx has five teeth on edge. The tube is narrow, longer than the cup. The flowers on short pedi- cel, collected in dense spherical umbrella with a diameter 4-10 cm. Corolla violet, blue, purple, red, pink or white. Bend like a wheel with a diameter about $1.5 \mathrm{~cm}$. The smell is weak, specific. The taste is sweet.

\section{Microscopic analysis of drumstick primrose}

Leaf. Leaf plate pubescent. The basic cells of the lower epidermis (Fig. 1) slightly elongated along the axis of the leaf, the side walls are thin, porous, finely winding, outer shell with soft folds of cuticle. Among ordinary cells many specialized cells that differ by the presence of orange secret. Stomata large, numerical, round, anomocytic type surrounded by 5-6 epidermal cells. Over veins (Fig. 1) narrow epidermis cells, more elongated, almost straight wall. Frequent trichomonas outgrowths of epidermal cells of two types. Small glandular hairs uniformly located, composed with short 1-2-cell legs and small unicellular head with dark content. Also on all surface, and the most densely on veins and along the edge of the plate, are found large, long, live, 3-12-cellsingle row hairs. One or several basal cells large, domed. Medial cell-segments wide, their shells are thin, usually easily distorted. Apical cells form small spherical colorless or dark head and a more or less distinct 1-2-cell narrow neck.

The upper epidermis (Fig. 2) without stomata, with less density of hairs. Basic cell larger, slightly elongated, their side walls slightly wavy or straight, many pores alternating with beads like thickenings. Teeth on the edge of the plate (Fig. 2) with secreting epidermis, densely covered with multicellular long hairs with elevated rosette of thin wall cells. Often several contiguous hairs form a bundle. Veins accompanied articulated milkman (Fig. 2) with bright orange content.

Leaf plate dorsoventral, hipostomatic. Main vein juicy, seems far from the bottom side. In the middle of it part goes the central conductive bundle, and at the place of transition to a leaf plate - 2 or 4 small side bundles (Fig. 3). Around the bundles and among main parenchyma many secretory idioblast of ovular- or rounded-paddle shape with dark content (Fig. 3). Also, meet milkmen with lighter

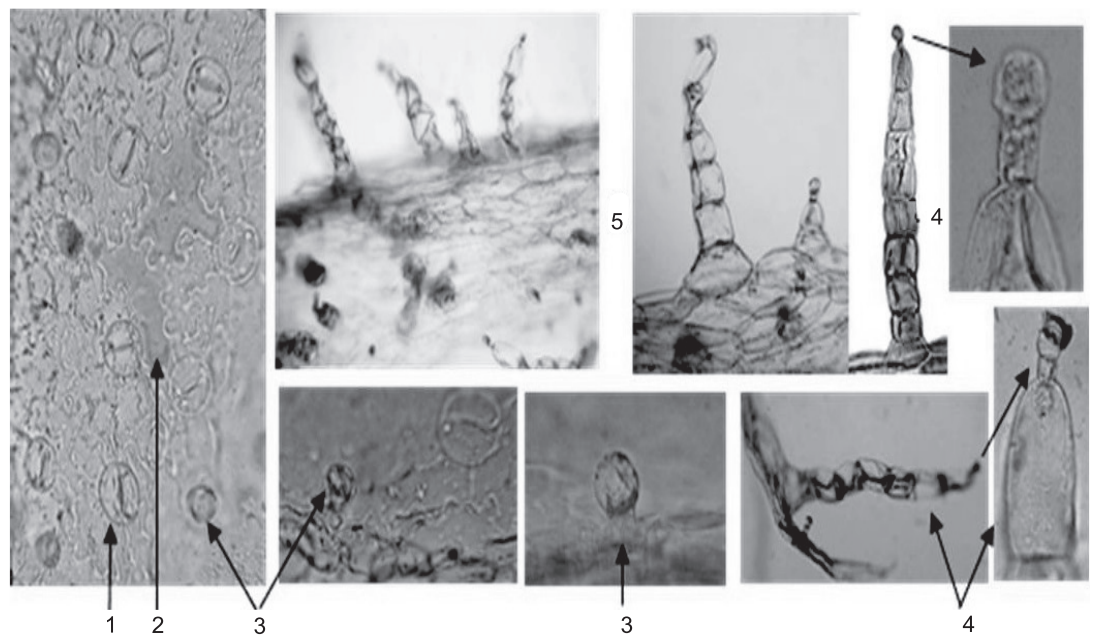

Fig. 1. The lower epidermis of leaves. 1 - stomata epidermis between veins; 2 - cell with a secret; 3 - small glandular hairs; 4 - multicellular capitate long hairs; 5 - the epidermis over veins 

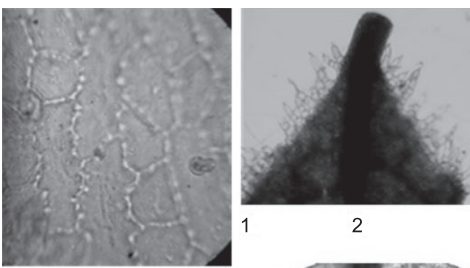

2
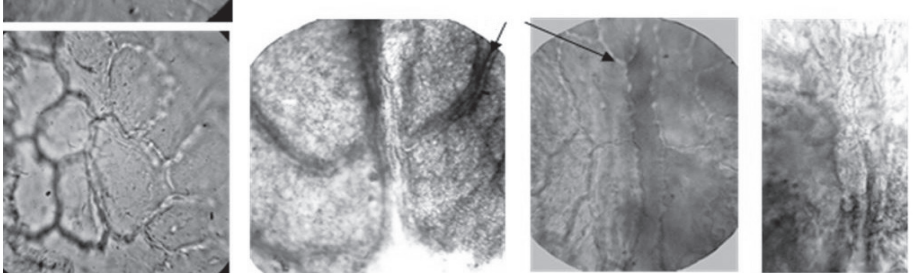

Fig. 2. The upper epidermis and leaf teeth. 1 - epidermal cells; 2 - tooth with pubescence; 3 - multicellular hairs along the edge of the plate; 4 - milkmen along the veins

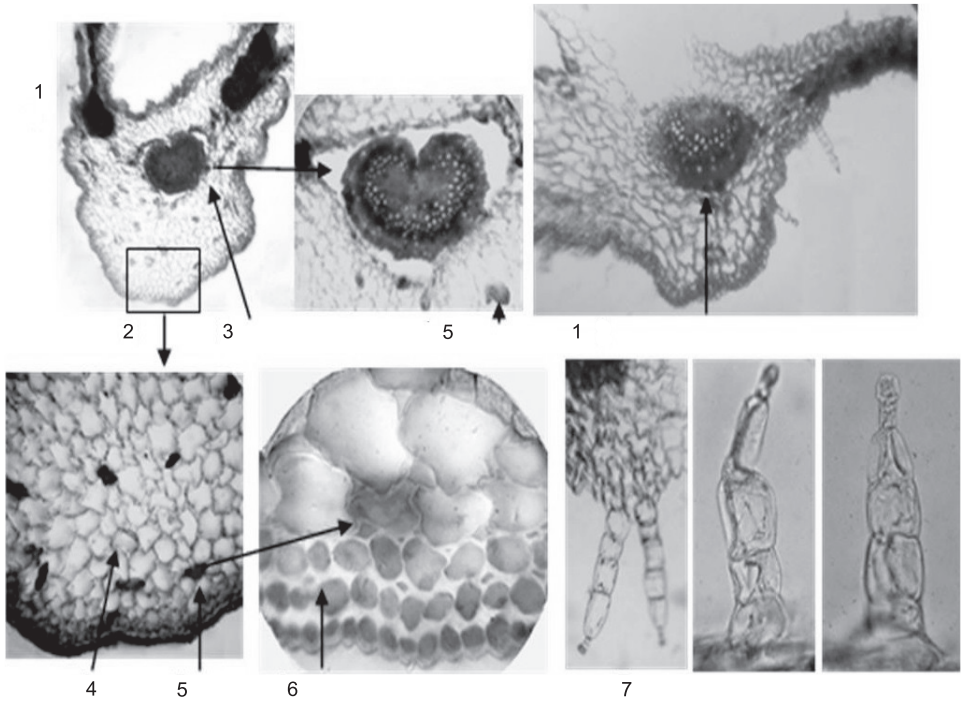

Fig. 3. Fragments of transverse cut of leaf plate and main veins. 1 - lateral conductive bundles; 2 - the main parenchyma; 3 - conductive central bundle; 4 - milkmen; 5 -secretory idioblast; 6 - kolenchyma; 7 - multicellular hairs

secret (Fig. 3). In the protrusion vein subepidermal kolenchyma composed 1-3 layers. Hairs on a vein a lot, they are typical for all above-ground parts (Fig. 3).

Peduncle cylindrical, increasing in diameter and lose core in the downward direction and becomes tubular. Anatomical structure transition. Stem at the top, under inflorescence (Fig. 4) correctly rounded shape, fulfilled by core of parenchyma. Covered by epidermis with a thick, almost continuous ciliary pubescence glandular hairs (Fig. 4), which have 1-2 cell foot and thin-walled oval head with yellow contents. Primary bark multilayer, replete with secretory cells and the milkman with brown contents.
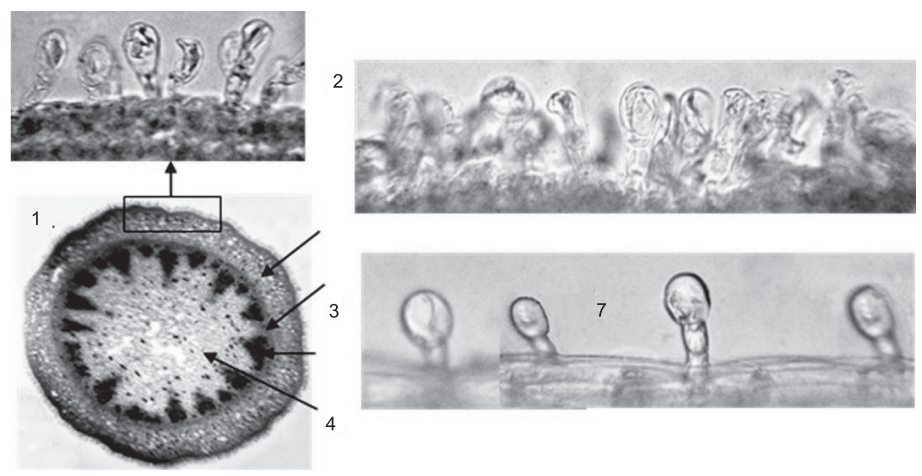

Fig. 4. Preparations of apical zone peduncle and pedicels. 1 - cross-cut peduncle; 2 - epidermis of peduncle with capitate hairs; 3 - primary bark; 4 - phloem; 5 -xylem of conductive bundles; 6 - core with milkman and secretory idioblast; 7 - capitate hairs of pedicels epidermis 

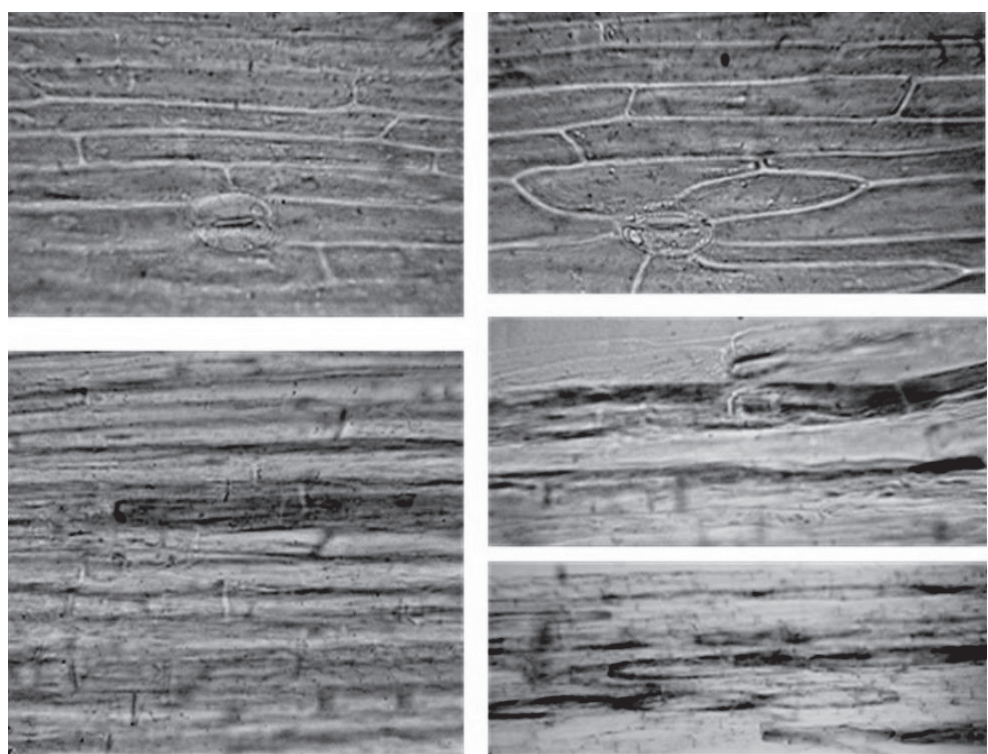

Fig. 5. Epidermis of middle and lower peduncle zones with stomata and milkman

This same secret accumulate endoderm cells. Ring of conductive bundles narrow, includes densely placed main larger collateral bundles and between them - a little additional bundles, formed by cambium that placed between the beam. In the bundles phloem merges and xylem forms a triangular protrusion, separated by parenchyma. Among the core parenchyma many dark secreto- ry structures. Pedicels have a similar structure. Capitate hairs of epidermis located uniformly, composed from 1-2-cell thin legs and rounded-oval head.

In the middle and lower zone peduncle become ribbed, epidermis (Fig. 5) without hairs, with oval stomata, placed by longitudinal rows. Epidermal cells elongated, narrow, their joints wedge-shaped. Right away under the
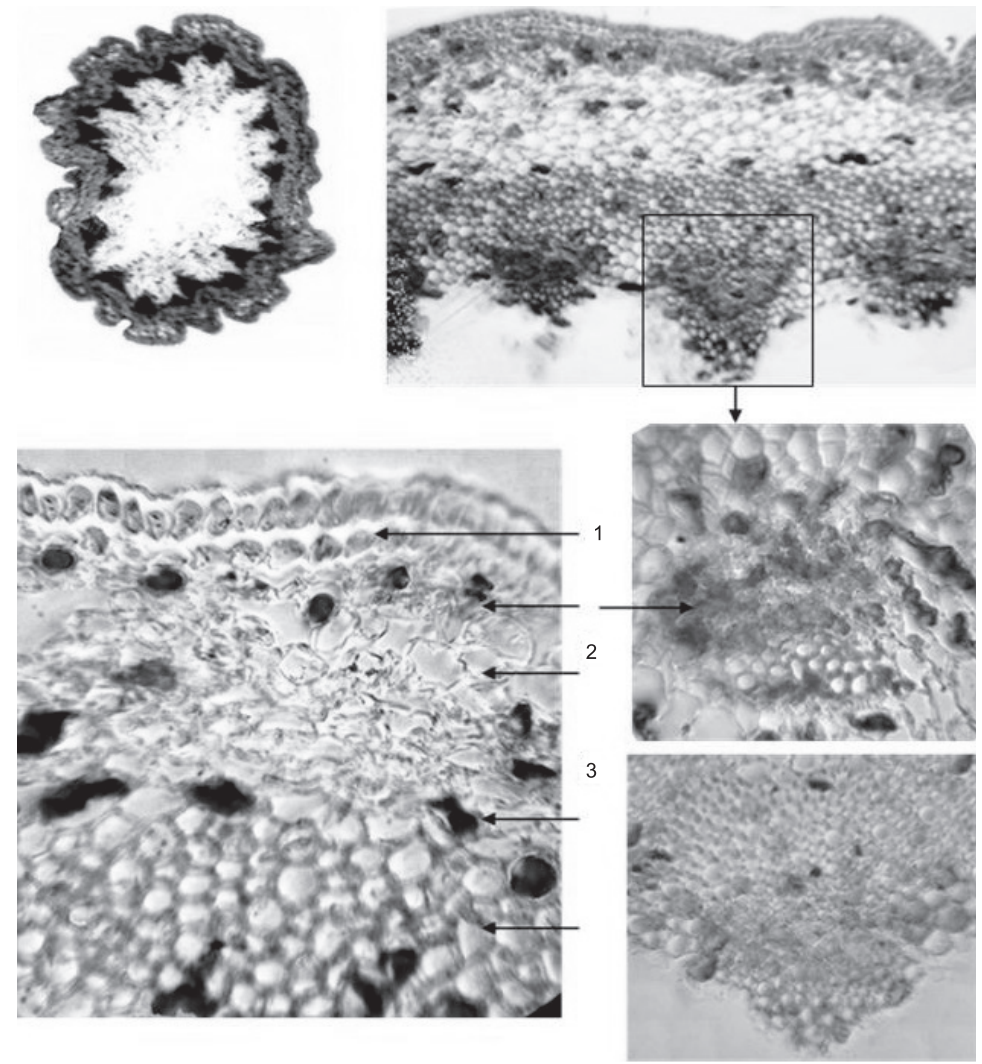

Fig. 6. Fragments of cross cuts of middle and downstream peduncle parts. 1 - kolenchyma; 2 - milkmen; 3 - bark parenchyma; 4 - sclerenchyma 

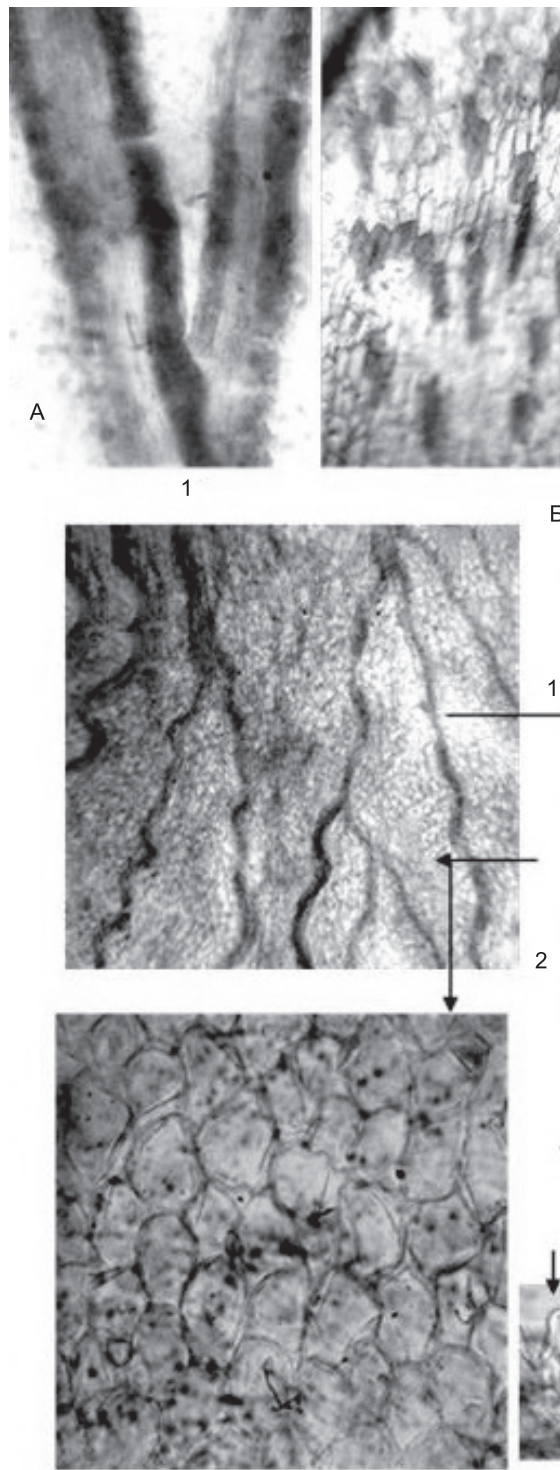

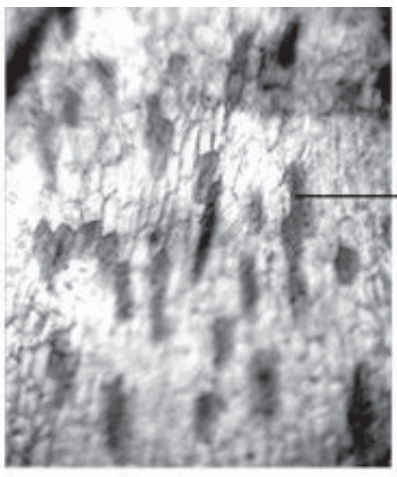

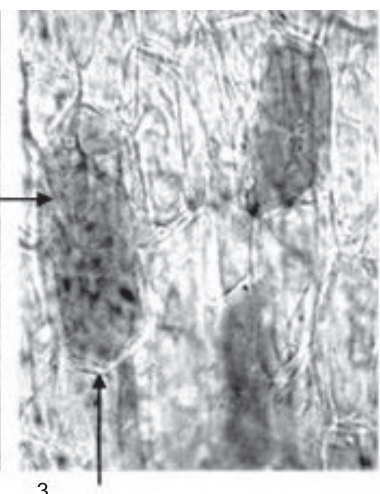
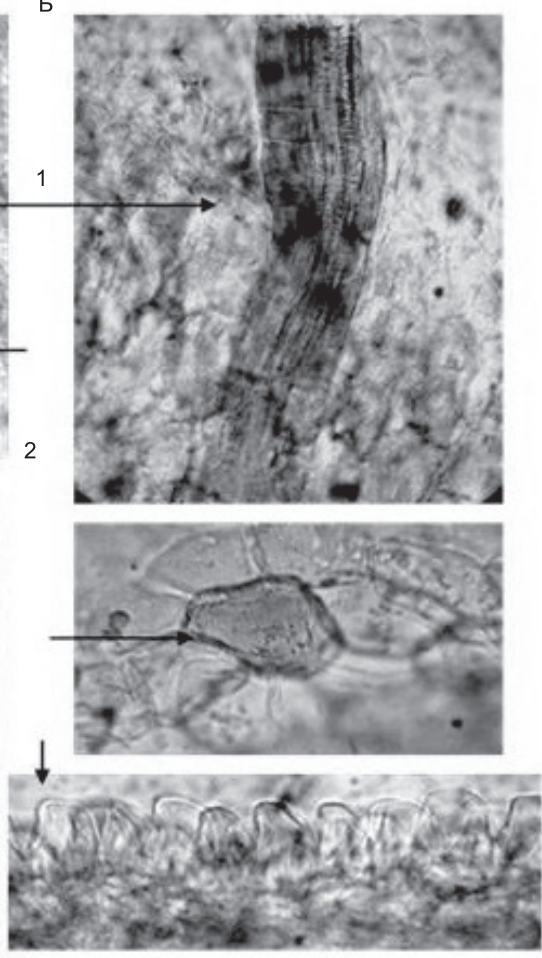

Fig. 7. Preparations of calyx (A) and corolla (B). 1 - milkmen; 2 - calyx epidermis, 3 - secretory cells, 4 - epidermis of corolla bend

epidermis or the single-layer kolenchym lying and densely connected with it segmented milkmen with a dark content (Fig. 5, 6). They also distributed throughout all primary cortex and the axial cylinder. Changes in the structure of the central cylinder, in compare with apical area, resulting in the formation of multilayer rings of pericycle sclerenchyma, increasing the diameter and reducing the width of the conductive rings, increasing the volume of the core and its almost total destruction at the bottom (Fig. 6).

Calyx (Fig. 7A) covered by rectangular elongated epidermal cells with slightly thickened shells. Stomata and hairs absent. In mesophylls, many dark secretory idioblast slightly elongated along the axis of sepals. Veins accompanied by segmented milkmen with a yellowish secret.

Corolla (Fig. 7 B) is also rich for secretory structures. Epidermis of tube make rectangular-rounded cells with a thin shell. Epidermis at bend similar papillary.

\section{CONCLUSIONS}

1. For the first time has been learned morphological and anatomical structure of drumstick primrose and dentified their main macro- and microscopic diagnostic features of over ground organs, that make it possible to identify and standardize new medicinal plan raw material.

2. The morphological diagnostic features: leaves without leafstalk, reaches $20-40 \mathrm{~cm}$ in length, collected in a dense rosette. Leaf plate wide thick, elongated, on the edge finely serrated, light green, pubescence, wrinkled and lumpy. Thick peduncles, covered at the top by yellowish cilia. Small flowers on short pedicel, gathered in dense spherical umbrella diameter of 4-10 cm; corolla violet, blue, purple, red, pink or white.

3. Anatomical diagnostic features of drumstick primrose: Leaf - leaf plate dorsoventral, hipostomatic; upper epidermis without stomata, with a lower density of hairs; 
basic cells larger than in the lower epidermis; lower epidermis with large, rounded, numerous stomata of anomocytic type; the basic cells of the lower epidermis slightly elongated along the axis of the leaf; among ordinary cells many specialized cells with orange secret; on the edge of the plate located the teeth of secreting epidermis; lower epidermis densely covered with hairs of two kinds.

Peduncles - cylindrical, increases in diameter and lose core in the downstream direction and becomes tubular; anatomical structure transition. Primary bark a multilayer, many secretory cells and milkmen with brown contents; ring of conductive bundles narrow, includes densely placed main larger collateral bundles and between them - a little additional bundles; core parenchyma contains many dark secretory structures. Epidermis covered by capitate glandular hairs.

Flower - calyx covered by rectangular elongated epidermal cells with slightly thickened shells; stomata and hairs absent; contain frequent dark secretory idioblast, veins with segmented milkmen with a yellowish secret. Corolla with secretory cells; epidermis of tube make rectangular-rounded cells with a thin shell; epidermis at bend similar papillary.

Conflicts of Interest: authors have no conflict of interest to declare.

\section{REFERENCES}

1. Марчишин, С. М. Анатомічна будова листя і квіток первоцвіту весняного (Primula veris L.) / С. М. Марчишин, Л. Г. Шостак // Фармац. журн. - 2014. - № 6. - С. 69-76.

2. Астамирова, М. А-М. Инвентаризация и анализ рода Primula L. (Primulaceae Vent.) Терского Кавказа и Дагестана : автореф. дис. .... канд. биол. наук: спец. 03.02.01 / М. А-М. Астамирова. - Астрахань, 2010. - 24 с.

3. Бавтутто, Г. А. Практикум по анатомии растений: учеб. пособие / Г. А. Бавтутто, Л. М. Ерей. - Мн: Новое издание, $2002 .-464$ с.

4. Грицак, Л. Р. Рід Primula L. (Primulaceae) у флорі України (систематика, фітохорологія, еволюція) : автореф. дис. ... канд. біол. наук: спец. 03.00.05 / Л. Р. Грицак. - К., 2000. - 20 с.

5. Лікарські рослини: енциклоп. довідник / під ред. А. М. Гродзінського. - К. : Голов. ред. УРЕ, 1989. - С. 326-328.

6. Астамирова, M. A-M. Морфологические особенности видов рода Primula L. Использование их полезных свойств населением Северного Кавказа / М. А-М. Астамирова // Вестник КрасГАУ. - 2011. - № 2. - С. 52-55.

7. Перебойчук, О. П. Перспективи використання представників роду Primula L. у квітникарстві лісостепу України / O. П. Перебойчук // Науковий вісник НЛТУ України. - 2014. - Вип. 24.4. - С. 112-119.

8. Примула мелкозубчатая — Primula denticulata Smith. [Электронный ресурс] // Энциклопедия декоративных садовых растений. - Режим доступа : http://flower.onego.ru/other/primul_g.html

9. Ковтонюк, Н. К. Секция Primula рода Primula (Primulaceae) во флоре России / Н. К. Ковтонюк // Растительный мир Азиатской России. 2013. - № 2 (12). - С. 61-73.

10. Серебряная, Ф. К. Сравнительное морфолого-анатомическое исследование надземных органов Северо-Кавказских видов рода Рrimula ᄂ. / Ф. К. Серебряная // Мед. альманах. - 2010. - № 3 (12). - С. 209-211.

11. Electron Microscopy. Methods and Protocols / ed. by Nasser Hajibagheri // Methods In Molecular Biology. - Humana Press, Totowa NJ., 2003. Vol. 117. -276 p.

\section{REFERENCES}

1. Marchyshyn, S. M., Shostak, L. H. (2014). Farmatsevtychnyi zhurnal - Pharmaceutical journal, 6, 69 - 76.

2. Astamirova, M. A-M. (2010). Inventarizacija i analiz roda Primula L. (Primulaceae Vent.) Terskogo Kavkaza i Dagestana [Inventory and analysis of the genus Primula L. (Primulaceae Vent.) Terskiy Caucasus and Dagestan]. Extended abstract of PhD dissertation. Astrahan', 24.

3. Bavtutto, G. A., Erei, L. M. (2002). Praktikum po anatomii rasteniie [Workshop on plant anatomy]. Minsk: Novoe izdanie, 464.

4. Hrytsak, L. R. (2000). Rid Primula L. (Primulaceae) u flori Ukrainy (systematyka, fitokhorolohiia, evoliutsiia) [The genus Primula L. (Primulaceae) in the flora of Ukraine (taxonomy, phytohorology, evolution)]. Extended abstract of PhD dissertation. Kyiv, 20

5. Hrodzins'kii, A. M. (Ed.). (1989). Likars'ki roslyny: Entsyklop. dovidnyk [Medicinal Plants: Encyclopedic Reference Book]. Kyiv: Holov. red. URE, $326-328$.

6. Astamirova, M. A-M. (2011). Vestnik KrasGAU - The Bulletin of KrasGAU, 2, 52-55.

7. Pereboichuk, O. P. (2014). Naukovyi visnyk NLTU - Scientific Bulletin of Ukrainian National Forestry University, 24.4, 112-119.

8. Primula melkozubchataja - Rrimula denticulata Smith. [Jelektronnyj resurs] [Drumstick primrose - Rrimula denticulata Smith.]. Entsyklopediia dekorativnyh sadovyh rastenii - Encyclopedia of ornamental garden plants. Available at: http://flower.onego.ru/other/primul_g.html.

9. Kovtoniuk, N. K. (2013). Rastitel'nyi mir Aziatskoi Rossii - The flora of the Asian Russia, 2 (12), 61-73.

10. Serebrianaia, F. K. (2010). Medicinskii Al'manah - Medical Almanac, 3 (12), 209-211.

11. Hajibagheri, N. (Ed.). (2003). Electron Microscopy. Methods and Protocols. Methods In Molecular Biology, 117, 276.

\section{Information about authors:}

Sinichenko A. V., assistant of the organization and economics in pharmacy and drug technology department, SHEI "Ivano-Frankivsk National Medical University". E-mail: annasinichenko@ukr.net. ORCID - http://orcid.org/0000-0003-3817-1801

Marchyshyn S. M., d. pharm. s, professor, head of the Pharmacognosy with Medicinal Botany Department, SHEI "I. Horbachevsky Ternopil State Medical University of Ministry of Health Care of Ukraine". E-mail: svitlanafarm@ukr.net

Sira L. M., c. pharm. s., associate professor of the Botany Department, National University of Pharmacy. E-mail: lyudmilaseraya@yandex.ru Відомості про авторів:

Сініченко А. В., асистент кафедри організації та економіки фармації і технології ліків, ДВНЗ «Івано-Франківський національний медичний університет». E-mail: annasinichenko@ukr.net. ORCID - http://orcid.org/0000-0003-3817-1801

Марчишин С. М., д-р фарм. н., професор, завідувач кафедри фармакогнозії з медичною ботанікою, ДВНЗ «Тернопільський державний медичний університет ім. І. Я. Горбачевського МО3 України». E-mail: svitlanafarm@ukr.net

Сіра Л. М., канд. фарм. н., доцент кафедри ботаніки, Національний фармацевтичний університет. E-mail: lyudmilaseraya@yandex.ru. Сведения об авторах:

Синиченко А. В., ассистент кафедры организации и экономики фармации и технологии лекарств, ГВУЗ «Ивано-Франковский национальный медицинский университет». E-mail: annasinichenko@ukr.net. ORCID - http://orcid.org/0000-0003-3817-1801 Марчишин С. М., д-р фарм. н., профессор, заведующая кафедрой фармакогнозии с медицинской ботаникой, ГВУЗ «Тернопольский государственный медицинский университет имени И. Я. Горбачевского МЗ Украины». E-mail: svitlanafarm@ukr.net

Серая Л. М., канд. фарм. н., доцент кафедры ботаники, Национальный фармацевтический университет. E-mail: lyudmilaseraya@yandex.ru

Рекомендовано д. фарм. н., професором О. М. Кошовим

Надійшла до редакції 10.01.2017 p. 